\title{
Transparency in supply chains and the lived experiences of workers and their families in the garment sectors of Bangladesh and Myanmar
}

\section{LEONA VAUGHN, ALEX BALCH, JENNIFER JOHNS and SAMANTHA CURRIE}

Abstract: This article explores the issue of transparency in supply chains for garment sector workers in two countries (Bangladesh and Myanmar). Drawing upon over 100 qualitative fieldwork interviews with workers and stakeholders, the article details the lived experiences of workers and their families. Their stories unveil the impact of factory operating practices and culture in a 'gendered workplace' on individuals and communities. Worker narratives are analysed to reflect upon the bearing of enhanced requirements on business stemming from the 'Transparency in Supply Chains' clause of the UK Modern Slavery Act 2015. The article presents evidence regarding the impacts of work in the garment sector in Myanmar and Bangladesh on the lives of workers, their children, and family life. The findings offer insights into the reality of the gendered workplace in supply chains for products manufactured in countries that are then exported to UK and worldwide markets. The discussion reflects on the value and appropriateness of transparency as a tool to address exploitation faced by workers in these sectors.

Keywords: Supply chains, transparency, modern slavery, exploitation, gender, children, garment sector.

\section{INTRODUCTION}

The rise of 'fast fashion' with its dependency on flexible and responsive systems of production has been associated with significant social and environmental costs in those low and middle-income countries where factories tend to be located (Bick et al. 2018). Bangladesh and Myanmar are two prominent examples of countries where the garment sector has grown rapidly in the context of weak and evolving labour regulation regimes and an emphasis on cost-cutting business models (Dennis \& Campbell 2017, Haque \& Azmat 2015). This article presents new evidence on experiences for 
workers and their families in these countries and explores the value of the 'Transparency in Supply Chains' clause of the UK Modern Slavery Act 2015 in addressing poor working conditions (Home Office 2017).

The idea of increasing transparency in business practices has become high on the public, political, and research agendas in national and global economic governance and environmental politics (Mol 2015). As a concept, transparency now carries considerable currency in debates about how best to address 'modern slavery'. It can be defined as one or both of the following: (a) a means of increasing the availability of accurate information, rendering visible which suppliers companies are working with and (b) an instrument to improve accountability through the tracing of negative consequences around poor sustainability practices (environmental, labour-related) to their original causes (Egels-Zanden \& Hansson 2016). The Modern Slavery Act's transparency clause is based on a combination of these ideas, with then-Home Secretary Theresa May describing it as a 'truly ground-breaking measure' and arguing that 'By requiring businesses to disclose what they are doing to eliminate slavery in their supply chains, we will provide a strong incentive for businesses to take this issue seriously' (Home Office 2015).

One of the starting points for our research was that, while most definitions of modern slavery refer to severe and criminal forms of labour exploitation, these practices and experiences lie on a continuum, with decent work at the other extreme and multiple forms and types of exploitation in between (Skrivankova 2010). Likewise, while modern slavery is normally an illegal practice, there are certain business models, including the use of low-cost and flexible labour, and the use of long supply chains, which can be linked to modern slavery: for example, by providing opportunities for it to flourish (Allain et al. 2013).

By identifying transparency as one of the key tools to tackle modern slavery in supply chains, the UK government is travelling in the same direction as many industry efforts and efforts driven by non-governmental organisations (NGOs) that see transparency as means of improving sustainability, something that is particularly the case in the garment sector. One example is the Fashion Transparency Index, which assesses and ranks brands and retailers across a range of indicators (Fashion Revolution 2018). The report claims that transparency is 'the first step to transform the industry' and described as 'like water ... seeping into some of the darkest corners, permeating the fabric of the industry' with the potential to flow into 'every deep nook and crevice, reshaping everything in its path' (3). Within the anti-sweatshop movement, led by groups such as the Clean Clothes Campaign (CCC - 'a global alliance dedicated to improving working conditions and empowering workers in the global garment and sportswear industries'), transparency is prominent in lists of demands. The CCC argues that requiring brands to publish supplier information 'could help workers by 
allowing unions and other labor advocates to alert brands to labor abuses in these factories. Knowing the multitude of brands that a factory produces for can help brands co-operate on solutions to labor rights problems.' The CCC claims that their \#GoTransparent campaign led to Primark publishing their factory locations (CCC 2018).

Despite this widespread enthusiasm for transparency as a means of addressing problematic working conditions, research into industry-driven initiatives on transparency has found mixed results. One case study is the campaign put together by Swedish company Nudie Jeans, where research found increased consumer demand rather than any leveraging of consumer behaviour in the direction of improving company accountability (Egels-Zanden \& Hansson 2016). It has been pointed out that increased transparency alone is unlikely to improve working conditions or address modern slavery, unless it is accompanied by a focus on gaps in governance (Crane et al. 2019). Since the Modern Slavery Act became law, the transparency clause has been the subject of much debate and calls to strengthen its impact. The Ethical Trading Initiative (ETI), for example, has argued that we know little about effectiveness, and that the lack of a central register, or the inclusion of government procurement weakens attempts to monitor and assess company efforts (ETI 2017).

The experiences of women and children in the garment sectors of Bangladesh and Mynamar have been at the forefront of discussions around exploitation and poor working conditions. Acker's (1990) theory of gendered work organisations points to the problem of the 'ideal worker' trope - someone who prioritises work over familyand how this permeates experiences of everyday work encounters, especially in relation to recruitment, staff relations, promotion, pay, and leave (see Britton 2000, Cha 2013, Collinson \& Hearn 1996, Glick \& Fiske 2001, Kucera \& Tejani 2014, Martin 2003, McLaughlin et al. 2012, C. Williams 1995, C. Williams et al. 2012, J. Williams 2000). Research on the gendered nature, or 'feminisation', of manufacturing industries of the Global South illuminates how gender informs the experiences of work in these settings (see Ahmed 2004, Bank Muñoz 2008, Caraway 2007, Plankey Videla 2012, Salzinger 2003). Additionally, claims have been made that these gendered practices are part of the transformation of work, such as the introduction of new technology, to respond to the high competition and demands of production to meet the needs of the Global North (Caraway 2007, Pozas Garza 2002).

The rest of this article contributes to the debate around fast fashion and its negative externalities by linking increased transparency requirements on UK-based garment companies through the Modern Slavery Act with working conditions in Bangladesh and Myanmar. The next section provides context by summarising key challenges and issues for workers in the Bangladesh and Myanmar garment sectors and comparing this with the modern slavery statements of UK-based garment brands. The article then turns to our interviews with workers in these two countries before discussing the potential for the transparency agenda to make a difference. 


\section{THE GARMENT SECTORS OF MYANMAR AND BANGLADESH}

What actions and initiatives involving international organisations and participants in the supply chain have been undertaken to address working conditions in these countries? In the case of Bangladesh, dangerous working conditions were horrifically highlighted by the Rana Plaza disaster in April 2010. A poorly constructed, eightstorey building containing an overloaded garment factory collapsed killing 1,134 garment workers and injuring over 2,000 more (Reinecke \& Donaghey 2015). It was found that the factory supplied companies such as Primark, Matalan, and Bon Marche in the United Kingdom. The disaster led to a host of leading clothing brands, including many from the United Kingdom, signing up to an Accord ${ }^{1}$-a legally binding agreement between global brands and retailers and trade unions.

The Bangladesh Accord, which had over 200 signatories from apparel brands, retailers, and importers, established a regulatory framework of independent inspections and remediation processes with the International Labour Organization (ILO) wherein many factories were made subject to safety checks for internationally required certification of safety. This agreement was in place for five years up to May 2018, but actions to mandate, for example, factory closures for non-compliance have lacked government support (Carlson \& Bitsch 2018). There is evidence of a reduction of worker deaths, but there remain serious concerns (Barrett et al. 2018).

In Myanmar, concerns have intensified about the extent of political reform and whether there has been a meaningful transition from full military rule in Myanmar's 'disciplined democracy' (Selth 2017). Since August 2017, the world has watched with horror the flow of refugees from the minority Rohingya Muslim community fleeing what the UN described as a textbook example of ethnic cleansing (UN News 2017). To put pressure on the government to address this crisis, in October 2018 the EU Trade Commissioner, Cecilia Malmström, notified Myanmar of potential trade sanctions by the EU on textiles, which could include withdrawal from the EBA ('Everything But Arms') agreement (Emmott \& Blenkinsop 2018).

The garment industries within both Bangladesh and Myanmar are historically female dominated at the bottom and male dominated at the top, with female workers traditionally restricted to low-paid positions deemed to require low skill and qualification (Mariani \& Valenti 2013). In Bangladesh the vast majority of RMG (ready-made garment) workers are women from rural areas (Asfar 2001, Yang \& Mlachila 2004). The sector is characterised as a pressured and competitive setting where low pay and job insecurity are endemic (Mariani \& Valenti 2013). This has a significant

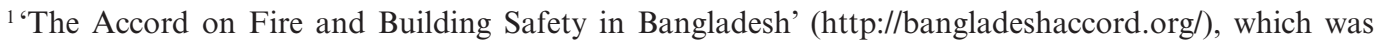
introduced alongside a second agreement - the Alliance for Bangladesh Worker Safety. 
impact on women who make up the majority of the workers in Bangladesh (Ahmed \& Raihan 2014, Kabir et al. 2018, Reinecke \& Donaghey 2015). Child labour was identified as an issue in the 1990s in Bangladesh, leading to an MOU (memorandum of understanding) in 1995 signed by the Bangladeshi Garment Manufacturers and Exporters Association (BGMEA), UNICEF (United Nations Children's Fund) Bangladesh, and the International Labour Organization (ILO) Bangladesh. Nielsen (2005: 561) suggests that the memorandum 'introduced a normative change in the way responsibility is distributed, essentially shifting it from the nation state to other societal actors, most notably corporations'. Significantly, the memorandum went beyond international law in terms of not allowing older children to perform light work (Nielsen 2005).

Over the last three decades, workers in Bangladesh have frequently protested about wages and working conditions. In the five years preceding the Rana Plaza tragedy, there was a period of striking and intense clashes between workers, factory owners, and the police. In response the Bangladeshi government formed the Industrial Police in October 2010, primarily to prevent and control worker protests and to reassure international investors and buyers. While perceived as the 'batons of the entrepreneurs' by workers, the public mission statement of the Industrial Police is to act as intermediaries, resolving disputes between workers and factory owners. There are currently 3,500 Industrial Police working across Bangladesh.

Better Work was an ILO and International Finance Corporation partnership, which operated in Bangladesh between April 2014 and June 2017. It aimed to build capacity at the factory and national structural levels to enable stakeholders to develop the most appropriate strategies to address problems. This included improving compliance with international and national laws and regulations, and improving working conditions, productivity, and quality (ILO 2018). This programme is contributing to efforts to close the 'enforcement gap': that is, the gap between standards set on paper and the reality (Nielsen 2005).

At the time of writing (early 2019) there was ongoing unrest in Bangladesh involving workers in the garment sector (IndustriALL 2019). While some improvements in work safety have been observed, there are still serious concerns about worker rights. The Accord is currently in the process of being replaced by the new 'Transition Accord 2018', a shift towards domestic governance and regulation. As part of this shift, the Bangladeshi government imposed a restraining order to enforce the closure of the Accord's inspection programme and enable government takeover of the regulatory work, even though the ability of the 'Remediation and Coordination Cell' (RCC) and its capacity to do so is in question (Preuss 2018, Safi 2018). Government is observed as having been unsuccessful in previous attempts to control the activities of 'entrepreneur' factory and business owners through regulation and legislation, with a large number of compliance issues in relation to enforcing labour laws for safety, minimum 
wage, and trade union activity (Butler 2016, Carlson \& Bitsch 2018). These issues are linked to high levels of worker protests, often violent, which the Industrial Police were established to address and thereby help to reduce the instability within the sector (Ahmed et al. 2014).

Anxieties about working conditions in the rapidly growing garment industry in Myanmar had, however, already started to emerge before the Rohingya crisis, alongside concerns about the country's ability to enforce legislation to adequately address them (ALR 2016, SOMO 2017). The nature of the type of 'cut, make, pack' (CMP) products in Myanmar, which in this setting requires raw materials to be imported, poses another set of challenges for ensuring good working conditions. The country is described as a significant provider of the quickly turned around 'fast fashion' products demanded by the rapidly moving markets of Asia and Europe (Fashion Revolution 2018, Workforce Disclosure Initiative 2017). The subsequent issues of labour rights abuses, including low pay, low unionisation, excessive overtime, and child labour, have thus intensified and are cited as posing urgent dangers to the sector (ALR 2016, SOMO 2017, Workforce Disclosure Initiative 2017).

In Myanmar, workers have been increasingly vocal (Radio Free Asia 2015) in expressing their dissatisfaction with these conditions. According to government data between 2012 and 2014, 447 demonstrations took place in factories within the sector (ALR 2016). In 2015, the country established a daily minimum wage of 3,600 Myanmar kyats, approximately $£ 1.80$. However, it has been argued that this still does not represent a 'living wage' for the country (Fair Wear Foundation 2016). This attempt by government to tackle low pay in the sector nevertheless took place in a context where compliance with labour laws is said to be inconsistent (Min \& Kudo 2013). In some cases, the minimum wage has not been implemented, or if it has, it has lowered income in real terms as, for example, employers increase pay deductions or lower the wages of more senior staff (ALR 2016, Falk et al. 2006, SOMO 2017, Workforce Disclosure Initiative 2017).

\section{Modern slavery act statements in the garment sector}

To what extent do modern slavery statements address the problems around working conditions in Myanmar and Bangladesh identified above? We gathered a random sample of statements for the sector using an online database (the 'Modern Slavery

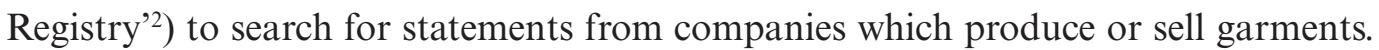
Our analysis confirmed other work that has noted that statements vary greatly both in terms of structure and in relation to the quality of information (Stevenson \& Cole 2018),

${ }^{2}$ https://www.modernslaveryregistry.org 
and a number which were non-compliant in terms of visibility or signature of a director (CORE Coalition 2017, ERGON Associates 2018, Phillips et al. 2018). There were mixed levels of transparency in terms of which factories companies were using. Six out of twenty-six published full names and addresses of all 'tier-1' suppliers; others published regions where they were located. Few companies state that they used UK garment factories, and for those which state they used factories overseas, they rarely explicitly differentiated between those which were owned by the company and those which were independently owned and contracted for production.

Most statements did not address risks in the lower tier of the garment production process: for example, detailing, embroidery, dyeing, washing, labelling. The fact that most statements concentrated on the primary tier of the supply chains but did not, or could not, address lower tier activity means that the supply-chain tiers most vulnerable to abuses, such as casual labour, subcontracting, and homeworking, were not within their purview. This, as some admitted, was because they did not understand the complexity of their supply chains at this point in time.

With regard to impacts on women, children, or families, there was almost no analysis in the reports suggesting any knowledge of associated problems or risks. A number of the reports made declarations regarding the non-use of factories employing child labour (under eighteen years old). However, they did not describe any proactive methods for checking on the age of workers, the legal definition of a child in the various geographical contexts (which is often fifteen years old), nor addressing the potential exploitation of children legally allowed to work in the local context. No statement included checking on the use of seasonal casual labour in factories for Christmas goods, for example, nor the use of subcontractors or outsourcing such as homeworking.

Bangladesh and Myanmar represent two cases where problematic working conditions in the garment manufacturing sectors are strongly gendered. The available evidence points to significant risks to workers and their families connected to the ways that UK-based companies source garments from these countries. The risk of exploitation combined with health and safety concerns have been linked with supply-chain pressures and weak labour protection. Moreover, due to the gendered nature of the workforce in this sector, these are likely to disproportionately affect women and their families. We argue that, if we are to maximise any benefits of the transparency agenda, it is important that this is integrated with an evidence-based understanding of the experience of work in countries where production takes place, and in particular how this affects women and their families. Only then can we demonstrate the extent to which transparency requirements brought in for UK companies under the Modern Slavery Act have the potential to address real problems of exploitation in garment supply chains, or have any impact in the lives of workers and their families in these countries. 


\section{METHODS}

Our research included desk-based analysis of the garment sector and modern slavery statements alongside fieldwork in Yangon (Myanmar) and Dhaka (Bangladesh). Working with local researchers, we designed the interviews to gather testimony on the experiences of workers in factories that supply big brand names.

These qualitative interviews were with an indicative sample of the labour force and stakeholders in each of the countries and sectors. We were interested in exploring the experience of working in these sectors, and how experiences/levels of exploitation vary according to the profiles of workers, and how this affects women, children, and their families.

Over the period of June-August 2018, 105 workers and stakeholders, including non-governmental organisations (NGOs), trade unions, and civil society, were interviewed about their experiences of work in the garment industry. We worked with local researchers to gain access to workers through 'gatekeeper' organisations, such as labour rights activists or unions, as well as through word of mouth. Anonymity and discretion were key to gaining the trust of workers and ensuring their safety. This was of particular importance for those workers in non-unionised factories and had differing local contextual issues. Interviews took place either in workers' homes or in neutral spaces identified by the worker, such as cafes or the 'gatekeeper' offices.

The Bangladeshi worker interviews comprised 29 female participants and 10 male. There were no participants under 18 years old; 4 were under 20, 25 aged 20-29, 9 aged 30-39, and 1 aged 40-49. The Myanmar worker participants consisted of 2 males, 1 unknown, and 38 females. There was one worker under 18 years old, 7 aged under 20, 27 aged 20-29, 3 aged 30-39, and 3 aged 40-49. Workers were often unsure of who they were providing their goods to, but it is known that companies such as Tesco, $\mathrm{H} \& \mathrm{M}, \mathrm{C} \& \mathrm{~A}$, and Next procure garments from the districts where these factories are located. We sought to analyse the gendered workplace through the lens of intersectionally lived experiences (Crenshaw 1995, Hill Collins 1990); that is, not just viewed through the binaries of male and female experiences, but how these overlap and intersect with issues of class, age, and parental responsibility.

Our local fieldworkers carried out the majority of these semi-structured interviews in the participants' first language, with some additional interviews with stakeholders undertaken by the authors in English. Researchers gained access to workers and stakeholders through a 'snowballing' technique (Kaplan et al. 1987), usually starting with an interview with a key stakeholder, such as a union or labour-based organisation, which would lead to introductions to other interviewees. It is accepted that this presents some limitations to the research findings in that experiences are geographically 
specific and may be biased towards those organisations or factories that have been suggested or recommended by others.

\section{FIELDWORK FINDINGS}

\section{Living wage and cost of living}

The question of pay emerged strongly in our interviews as a problematic and stressful issue for many of the workers we interviewed. The minimum wage - which exists in statute in both countries - does not appear to be honoured by all employers. If it is, we found numerous instances where workers were accusing their employers of avoiding proper rates of pay. Firstly, by deductions for minor transgressions or unavoidable issues such as not meeting targets, not being on time, or being ill. Secondly, by expecting workers to undertake overtime to complete time-pressured orders without additional pay. These are obvious examples of labour exploitation; however, the unseen consequences of pay which is lower than the cost of living include having to compromise on issues affecting personal safety, health and well-being, and family life:

I maintain a food chart because I need to calculate my expenses. ... It's not good. It's too tough to bring up two kids with this poor income. They are growing fast. Prices of essentials are increasing faster than our pay. Now we badly feel that they need their separate rooms, they are of that age. But we can't afford a big house. I don't even invite my relatives to my house.

Ban W19 (female, 40)

Many workers told us they were cutting back on buying expensive foods such as meat or fish. These can be linked to decisions that have deleterious consequences for health: for example, through poor diet. They also can be linked to choices regarding living arrangements which are connected with consequences for the safety of workers, for family life, and separated families:

I live in a slum. It's populated and noisy. Otherwise it's safe, roughly clean, nearby bazaar. I stay here alone, we can't afford to have the family living here. ... I am working hard to pay back some loan we took to buy an auto rickshaw... I'm happy. Only when I see someone breast feeding, it breaks my heart because I had to leave my two months baby boy for job. I rarely can see my son. I stay here alone with my colleagues.

Ban W15 (female, 26)

Where I live, as women, it's not safe for travelling and even while showering. Being away from my family, my family feels like strangers. We are not so close anymore.

Mya 34-39 (focus group) 
The examples we found in our research not only outline the material impacts of earning less than a living wage on the lives of workers and their families; they also point to the emotional impact and distress which arise from estrangement from families.

\section{Violence in the workplace: experiences of aggression faced by workers}

One of the most shocking findings in our interviews with workers was the frequency with which we heard of examples of aggression and violence (two thirds of all the workers we interviewed). Verbal and physical violence towards shop-floor workers was outlined as commonplace; staff described being regularly hit or shouted at, especially during the highly pressured time of preparing goods for deadlines:

I once got promoted to leader but I wasn't happy and I quit. They demanded higher targets and told me that I had to shout and swear at the workers to demand these targets. When the targets didn't get met, they shouted at everyone. To meet their target demand, sometimes it is really difficult. Some of the pieces were really hard to make.

Mya W26-33 (focus group)

The sexualised and gendered nature of this verbal abuse was notable. For female workers, even those few who had managed to secure more senior roles, sexual violence, including physical touching, references to genitalia, labelling women as sex workers, and offering of money or workplace 'advantages' in exchange for sex, appears to be normalised practice:

Sometimes the line chief gives bribe to the admin official to increase those workers' salary who have a good relation with him, the good-looking ones. ... Our line chief and supervisor are very bad persons. Their behaviour is too bad. It is not possible to mention the words they use with the workers. Abuse is a regular event that happens in our factory. If any worker, mostly the women, fail to meet their target, they have to hear swearing those words. Often they call us whore-child, bitch etc. for very small issues and no good reason.

Ban W6 (female, 22)

Managers do not behave badly with me. I work in the quality section, comparatively educated people work here. So we don't have to receive verbal abuse. ... If anyone can't fulfil the target, they get abusive words. Sometimes they call the female workers 'magi' [prostitute]. One of our female auditors she uses bad language like 'store your juice in your vagina.' Yesterday the auditor was yelling with a male operator. He was working slower than others. Then the auditor, in front of everyone, said 'Are you a man or a eunuch? Work fast or I will remove your balls.'

Ban W18 (female, 22) 
The indication in the experience of Ban W18, is that workers who are in a more skilled position and therefore who have higher levels of education are less likely to be affected by violence and aggression in the workplace. This implies that there are significant issues of power and privilege in workers' experiences. This is further illuminated by examples of age and sexuality impacting on the nature of the experience of workplace violence and aggression:

I've had discrimination against my gender, because of being a tomboy. Being a LGBT. I don't want to tell my parents about bad things at work because I don't want them to feel sad.

Mya W19 (female, 25)

If I am sick, first they swear at me. If I say no to overtime they swear with the microphone. The managers start to swear since the morning. Shouting and swearing constantly. They even hit my head. ... If I make mistakes with the clothes, they deduct from my salary as well swear at me.

Mya 23 (female, 17)

Our evidence points to the fact that the experience of gendered violence at work is thus multi-dimensional and impacts on different people, in different roles, with different backgrounds differently. In our sample it was, nonetheless, widespread.

\section{The evolution of the gendered workplace}

In Myanmar, our worker participant group consisted of 95 per cent female workers and in Bangladesh this figure was 75 per cent, reflecting trends in the sector. It should be noted that the increased engagement of women in the workplace, in some cultural contexts hitherto admonished or resisted, has been claimed by some to have had a positive impact on the advancement of gender equality (Ahmed 2004). This claim should, however, be balanced against experiences of gender-based inequalities in pay and workplace experiences, and wider persistent structural gender inequalities in health, education, law, and wider society. We were also told that in Bangladesh the gender balance is changing:

Right now, women are about 55 per cent of the workforce. It's going down. They [employers] said that, because they now have to abide by the maternal protection and those laws, the women workers are more costly for them, so they're not hiring them. As if they were actually paying them their maternity benefits, in the first place!

Ban S15

This was replicated across both locations wherein there is a perception that the previously female-dominated workforce is set to be no longer a reality within the 
garment sector. We found four significant categories of factors impacting on decreasing female representation in the workplace.

The first of these was that women of child-bearing age are viewed by employers as likely to get pregnant and become an economic burden to the factory. The majority of female workers in both countries were in the age range of 20-29 years of age, but workers talked of a constant turnover of staff and feelings of precarity or insecurity in their positions. Their acounts of working practices indicate that employers are finding ways of avoiding or working around their legal responsibilities for actions, such as in the example given above of providing maternity benefits. Maternity rights and pregnancy 'monitoring' are issues consistently raised by workers and stakeholders alike in both countries, and will be returned to later in this section.

The second issue related to age and disability. We found that older women and those who have developed physical disabilities or restrictions were being targetted and 'managed out' of the workplace through bullying, unachievable targets, and wage deductions. Workers recount workplace assumptions in workers and management about performance and productivity for these groups:

They don't want older people to work there because of they are less productive. So they create such situation so that the older workers leave job.

Ban W14 (female, 26)

The third issue related to pressure around productivity. Stakeholders told us of a link between the introduction of new technology or equipment (to increase productivity or work with specific materials such as leather or denim) and a reduction in the numbers of women in factories. Women workers, who have previously undertaken roles labelled as 'low skilled' and needing no or little training or formal education, are relayed as being judged incapable of undertaking these more specialist job roles. This supports the conclusions of others such as Caraway (2007) and Pozas Garza (2002) in their studies of female workers in Indonesia and Mexico, who noted that the advancement of automated technology in the development of garments is potentially 'de-feminising' the industry (Caraway 2007, Kucera \& Tejani 2014). In other words, there is a resultant increase in the numbers of male workers entering the sector because they are assumed to be more skilled in this type of work. Garment workers again recounted experiences or observations of practices in the workplace to dismiss or sanction, through disciplinary actions and wage deductions, which specifically targetted women who could not keep up with increased demands for productivity or flexibility in roles or use of equipment. Older women, pregnant women, or women who had sustained workplace injuries and consequently had to adapt their work or role accordingly, are described as being routinely subject to these actions. Therefore, these women are more vulnerable to being dismissed first in the process of de-feminising the factory: 
I heard the managers are making adding older workers' name to elimination list recently. One of my colleagues BK, she is aged sixty. She is also in the list. But her productivity is not less than any other worker. She has no one in this world. Her husband died, she has no children, no relatives. Now, if she loses her job just because of her age, where will she go?

Ban W21 (female, 28)

The fourth issue connects to the perception that women are 'leaving' the sector and therefore exercising agency in their decision. If this is the case, this issue needs further exploration through future research. Most of the workers we interviewed reported that they did not have any experience of any other form of work; they often expressed that they had no other choice but to remain working in a job that they were often unhappy with. Workers suggested that those who are leaving the workplace, especially if they are older workers with a similar work history to the workers within this study, have few options but to remain in the sector, but further down the supply chain in less-regulated or unregulated settings such as homeworking:

The people in cleaning, cafeteria, and security are mainly older workers. The employer gives them a fixed salary so that they get the minimum wage, but they often don't get overtime. They have to stay with the normal workers while the factory is open, and the conditions are worse. ... There is a lot of subcontracting to home-based factories-can be one person, three people, twenty - anything. For them they get paid by piece rather than a minimum wage. Home-based factories still get a minimum wage but they don't get any benefits or guarantee of the work and the employer doesn't take any responsibilities. They are mostly old women because the factory doesn't want to hire them anymore, and also women with children for flexibility and for people without ID card, and for children who are too young to work.

Mya (S01)

Rather than being based on a decision made freely to leave the sector, an alternative explanation relates to intolerable conditions making their position untenable, and relates back to the problem of gendered workplace violence and aggression.

\section{Impacts on family life}

Beyond the day-to-day experiences of discrimination, gender-based divisions of labour and tasks and gendered experiences of bullying and harassment is the less visible impact of the gendered workplace on workers' children and family life. The experiences of a culture wherein the 'idealised worker' places work before family have very real impacts. These are observed in relation to women workers' reproductive rights and choices, including monitoring and surveillance of pregnancy and circumvention of maternity rights, and the phenomenon of workers being separated from their families. 
I used to have a problem, I got fired because I didn't work fast enough, I was pregnant at that time.

Mya W40 (female, 27)

Nearly all workers in Myanmar relayed that getting pregnant was universally 'not allowed' and that it was commonplace for workers to be asked about family planning or undertake a pregnancy test on recruitment and randomly during employment. Consequently, workers here did not relay many experiences of pregnancy in the workplace. Similarly in Bangladesh, workers relay issues of being 'monitored' for pregnancy:

[on recruitment] They asked me whether I am pregnant or not. If anybody is found pregnant after joining the factory, they will be terminated and will not get any benefit.

Ban W7 (female, 25)

Nonetheless, the topic of 'pregnant women in the workplace' was far more frequently referred to in Bangladesh, than Myanmar. Workers in this country could therefore give a far more detailed insight into this group's treatment:

Our maternity leave is 112 days. But, if the new-born baby dies, authority curtails the leave. Recently, two workers' babies died after birth. Management sent letters to them to join office immediately ... pregnant workers here are in miserable conditions. They also have to work till 7 PM before the day they go on maternity leave. They are not allowed to take rest during the working hour. They work like other workers. It makes me feel bad.

Ban 32 (female, 25)

Workers relayed that employers were finding ways to work around the legal entitlement to maternity leave by making additional rules or exclusions which reduce the cost to the factory in relation to pay and reducing the time a worker is away from the production line:

Bangladesh law says that after six months of your continuous service then you will be getting the maternity benefits. So the employers sometimes ask the workers that you cannot be getting pregnant or anything within two years of your service. So it's not written anywhere but unofficially it's a trend through the messaging with the welfare officers who say that okay, if you work this factory you will not be eligible for the maternity benefits if you are pregnant.

Ban S15

There are 120 days for maternity leave at my workplace. But technically, the office sends the pregnant workers on leave just after eight months of pregnancy. After delivery, a postpartum mother gets only 56 days for maternity leave, meaning that she cannot enjoy the full maternity leave. 
Not only do workers relay that workers do not get their legal entitlement to maternity leave and pay, but also their experience at work is arduous. Regularly workers recount experiences or observations of pregnant women undertaking physically demanding tasks in the workplace and being expected to fulfil overtime and meet the same targets as other staff:

I work ten hours per day and sixty hours per week. Every day I have to work two hours of overtime per day and twelve hours per week. Who likes to do overtime when she gets pregnant? Now I am pregnant, so it is not easy to work all day long without break. If I refuse to do overtime more than that, they will shout, misbehave, or eliminate me.

Ban W22 (female, 21)

Moreover, we found evidence of both employers restricting the rights of workers to have children accompanied by the phenomenon of workers self-restricting their reproductive choices:

I myself decided not to take more children since I am not able to meet all the demands for my one child with this nominal monthly income.

Ban W1 (female, 48)

\section{Disruption and separation of families}

The expectations of the 'idealised worker' are shown to have a significant effect upon how workers experience a disrupted family life and relations. Workers indicate that in order to take up work in the factories, often located in busy factory districts either within the city centre or in the suburbs of the cities where workers are expected to live on site, they must accept separation or estrangement from children and their wider family. This was expressed as the norm in both countries:

I left my kid with my parents in the village so that I can do the job and feed her. But my parents are not affluent to take care of me and my daughter. Moreover, with my little education I was not able to find another job. I am a single mother now and I have to live my life alone with my baby girl who lives in the village with my parents. So, it is very hard to afford all these expenses like food, house rent, clothes, and tuition fees and so on with this poor salary. I live in a rented room with my colleagues in a slum. I stay here alone. I used to cry all day long for my baby girl when I came here, she is so adorable. I can't take leave to see her. I was with her two months ago, during Eid vacation.

Ban W17 (female, 22)

Workers are making this choice out of economic necessity; the decision to move away from family or to keep children at home in their family village in kinship care arrangements are relayed as a direct result of not earning a living wage. For male workers, this separation is portrayed as something which just has to be done. They often 
express that long hours, required to bolster their low pay, is negatively affecting their relationship with their wives and children by reducing the time that they have to support their family through events such as pregnancy, child-rearing, or housework:

I didn't get leave while my wife was pregnant. I work sixty hours a week here, sometimes more, and stay away from my family. They are in the village. I can meet with my wife and daughter twice a year.

Ban W11 (male, 27)

I travel in from my village to a meeting point with motorbike or three-wheel bike and then on to factory with transportation provided by factory. It is not very safe at all. It also means my day is very long. That causes big fights with my wife because of late working time. Also I am not able to give time to my children. I usually ask for leave for going back before or after Thingyan [Myanmar New Year; water festival], but I don't always get it.

Mya 26-33 (focus group)

For female workers, they express this separation in similar ways as a necessity for the work and income:

I came to work here because of my sister. I moved here and share with my colleagues. It is not good. I work 63 and a half hours a week. I don't see my family.

Mya 23 (female, 17)

While children and young people did not account for a large proportion of our participants, we were told of a number of risks to safety, health, and well-being for young workers who are away from family in cities they do not know, working hours which exceed those of their colleagues for less pay. This includes exposing this group of workers to riskier work or situations. Mothers told us that work required them to separate from their children or husbands as necessary to provide funds for food, clothes, and education. This decision is also often related to taking on responsibility for family debt or bills, and has wider impact on their kinship networks:

I sent my husband abroad so that he can earn more money for a moderate life and secure a future of us, especially for our daughter. I took loan for that, and I am repaying the debt. But he is not doing well there. It's low income and hard work. On the other hand, here I am doing my job for fifteen years. So, for yearly increment I earn more than him and my overtime rate is also high. I am scared, if I lose this job, I will be in big trouble. I have heard that most of the factories eliminate the older workers who are working there for long time and comparatively highly paid.

Ban W27 (female, 30)

From the experiences we recorded and analysed from our interviews, it is clear that the negative impacts of the 'gendered workplace' ripple across both low-paid female 
and male workers. There are significant disadvantages for women, and substantial consequences for children. The gendered workplace has an impact on the quality and ability to have a form of family life: relationships and connection to family are strained and sometimes broken by the requirement to work and the low level of pay. The emotional impact on parents' well-being, is compounded by poor maternity and paternity leave rights and benefits. The experience of low-paid parents has a direct impact on health and nutrition for children. On the one hand, the decision to leave children with families is often relayed as a financially sound decision based on the low wages and high living costs of being closer to work, which benefits children staying in areas with lower costs of living and family support. On the other hand, children are experiencing emotional and physical loss and separation from parents in a situation formed out of necessity rather than free choice.

\section{DISCUSSION AND CONCLUSIONS}

The characteristics of the 'gendered workplace', expressed by workers in both countries, build a picture of an environment that is stressful, discriminatory, oppressive, and exploitative for all workers who experience it. Our evidence shows that this impact is variable and manifests in different ways for different categories of workers, but the main vulnerable groups are pregnant women, and older and disabled workers.

If, as the participants in our research suggest, these groups are being targetted for sacking, discipline, and sanction/wage deduction, then it is reasonable to conclude that they are most at risk of more severe forms of exploitation. This may be through being squeezed out into related but even less regulated work in more extreme circumstances. Connected to this form of workplace pressure is the risk of damage to children and families. Our work shows that the low wages, long hours, and poor working practices in the garment sector can have acute consequences for the health and well-being of families. These were issues almost completely ignored in the modern slavery statements that we analysed as part of this research.

The underlying hypothesis underpinning Section 54 is that laws requiring, or encouraging, a level of social disclosure will enhance transparency. In turn, the idea is that this will bring pressure to bear via the 'reputational implications' (Nolan \& Bott 2018) of such transparency requirements for companies. This is expected to be as a result of shifting consumer behaviour, but also with regard to broader power dynamics: for example, with the government, NGOs, or even shareholders using the statements to lobby companies to change their behaviour. But how does this relate to the specific issues encountered in gendered workplaces such as those of the garment sectors of Bangladesh and Myanmar? 
Law and policy requiring businesses to report in this way seeks to respond to the transnational nature of supply chains, which are now 'ubiquitous in the global economy, found in every industry, and on every continent' (Ruggie 2013). This expansion of supply chains that cross a number of borders and link together a number of enterprises of varying size and economic status, operating in different social, legal, and political contexts, has also facilitated the creation of conditions in which workers within the chain can experience poor working practices. This can include those that fall within the 'modern slavery' umbrella, as some business practices within these chains have eroded respect for, or simply disregarded, human rights, and such practices have most acutely impacted precarious workers, including informal, migrant, contract, and female workers in global supply chains (Phillips 2017).

The broadness of the definitions within the MSA of modern slavery as 'slavery, servitude and forced or compulsory labour' and human trafficking as 'travel with a view to $\mathrm{V}$ [victim] being exploited' are potentially being reinterpreted or misinterpreted by businesses, with the issue of 'exploitation' being particularly difficult to define concretely. Exploitation is rarely viewed in the context of a continuum of labour abuses, or in the context of family life or gender.

This misunderstanding of what constitutes exploitation is then exacerbated further by the wide interpretation of what constitutes 'the supply chain'. Supply chains are inherently difficult to regulate under a traditional 'domestic' model of law. Over the last three decades, supply chains have become increasingly complex due to vertical disintegration and the increasingly transboundary nature of production and consumption. Loconto (2015) observes that, as supply chains extend their reach across geographical space, they are increasingly becoming a key mechanism through which private and civic actors can 'govern at a distance' (Busch 2007, Miller \& Rose 1990). The range of legal jurisdictions through which a chain can pass, and the differing natures of the economic, social, and labour standards within them, renders it difficult - legally and practically_-for domestic law to address anything beyond conduct that occurs within the particular national territory.

The findings presented here are significant because transparency requirements are now becoming more prevalent at the domestic (home-state) level of regulation. ${ }^{3}$ Such disclosure as has previously been encouraged, in a soft-law and non-binding sense by voluntary codes of conduct and guidelines, is now legally required by legislation such as the MSA and the The California Transparency in Supply Chain Act (CTSCA). The key issue is whether this obligation to be transparent about action taken to address issues such as forced labour and slavery in supply chains, is sufficient to bring about practical and meaningful changes to business operations. Research carried out in the

${ }^{3}$ Australia’s Modern Slavery Bill (2018) also contains transparency provisions. 
UK context relatively soon after the MSA came into force pointed to the tendency of most companies to disclose general information about existing policies, but a significant number ( 35 per cent) failed to give any details about risk assessment processes (ERGON Associates 2018). There is clear potential, then, for the approach to transparency reflected in the MSA and the CTSCA to result in procedural (cosmetic) (Nolan \& Bott 2018) compliance with the terms of the law, without invoking any substantive action on the part of the businesses concerned.

Transparency is more likely to impact on a company's activities with regard to their supply chains if it goes beyond mere reporting and is inclusive of due diligence and has strong enforcement mechanisms. ${ }^{4}$ Neither the MSA nor the CTSCA contains any pecuniary or criminal penalties for those companies that fail to comply. In the United Kingdom, civil proceedings can be brought in the High Court for injunction or specific performance of a statutory duty, ${ }^{5}$ but this is a weak sanction for companies in light of the low threshold set for the detail that statements must contain. Even if such civil procedures were 'successful' in compelling a company to produce a statement, it would still be open for the company to say only that no steps had been taken to address modern slavery.

It is clear that the legal requirement to merely produce a statement under the MSA has not transformed what has historically been a soft-law commitment to be transparent into a hard-law obligation with genuine legal consequences. Weaknesses include the limited nature of the actions needed by companies to comply with the TISC (Transparency in the Supply) requirement, the lack of available verification mechanisms to follow up on information provided and limited sanctions for non-compliance. As Mantouvalou (2018: 1038) points out, 'The MSA did not attempt to pierce the corporate veil with hard legal rules and sanctions for non-compliant businesses.'

There is certainly a place for transparency, and it has been a useful concept for building support for business, as well as government, taking a level of responsibility for human rights risks within practices and supply chains. Supply-chain transparency has many shortcomings, from limitations around how information is collected and disseminated, used, used by whom, and to what effect (Mol 2009, 2015). It is generally assumed that transparency can empower the powerless in supply chains, but it can also empower the powerful and become an instrument in furthering inequality in value-chain operations (Mol 2015). In addition, transparency differs by use and by scale (McDermott 2014). Gardner et al. (2018) argue that information that is

${ }^{4}$ The House of Lords and House of Commons Joint Committee on Human Rights recommended such legislation be brought forward in the United Kingdom in its report on Human Rights and Business 2017: Promoting Responsibility and Ensuring Accountability (para. 114).

${ }^{5}$ Section 54(11) MSA 2015. Similarly, under the CTSCA, injunctive relief can also be sought. 
transparent, accessible, and reproducible to a national government, multinational corporation, or highly resourced NGO differs from that which is transparent and accessible to local producers and communities. Transparency is not a universal concept in either design or enforcement, and, thus, local context is a significant mediating factor in its 'success'. So further and continued local studies conducted using rigorous fieldwork are required in order to understand the impact of existing legislation and to effect meaningful improvements.

In recent years, there has been recognition at the international level that corporations also have a responsibility to respect human rights: for example, the UN Guiding Principles on Business and Human Rights in 2011 (United Nations 2011). While these are only 'soft' law, they have contributed to the creation of a 'social expectation' (Nolan \& Bott 2018) and raised awareness of the role that business can play in raising standards of human rights protection. The Modern Slavery Act, along with its transparency requirements, can be seen as part of this general trend towards a recognition of business responsibility to protect, and safeguard, human rights. However, the findings here from one sector and two countries, where we found abundant evidence of problematic working conditions, is that the enhanced requirement for transparency does not appear to offer an appropriate means with which to address actual lived experiences of exploitation and human rights abuses in supply chains.

\section{Acknowledgements}

This article presents findings from the BA-DFID-funded project 'Clothes, Chocolate and Children: Realising the Transparency Dividend', a 16-month project based at the University of Liverpool. The project focussed on the value of the transparency agenda - in particular Clause 54 of the UK's Modern Slavery Act (2015), in addressing problematic, working conditions in cocoa and garment supply chains. ${ }^{6}$ The study considered one commodity (cocoa) and one manufactured good (garments) in four low and middle-income countries: Bangladesh, Dominican Republic, Ghana, and Myanmar.

\section{REFERENCES}

Accord on Fire and Building Safety in Bangladesh. http://bangladeshaccord.org/ Acker, Joan (1990), 'Hierarchies, Jobs, Bodies: A Theory of Gendered Organizations', Gender and Society, 4: 139-58. https://doi.org/10.1177/089124390004002002 ${ }^{6}$ Awarded to Prof Alex Balch, University of Liverpool, as part of the DFID-BA programme, https://
www.thebritishacademy.ac.uk/tackling-slavery-human-trafficking-and-child-labour-modern-business 
Ahmed, F. E. (2004), 'The Rise of Bangladesh Garment Industry: Globalisation, Women Workers and Voice', NWSA Journal, 16(2): 34-45. https://doi.org/10.2979/NWS.2004.16.2.34

Ahmed, F. Z., Greenleaf, A. \& Sacks, A. (2014), 'The Paradox of Export Growth in Areas of Weak Governance: The Case of the Ready Made Garment Sector in Bangladesh', World Development, 56: 258-71. https://doi.org/10.1016/j.worlddev.2013.11.001

Ahmed, S. \& Raiman, M. Z. (2014), 'Health Status of the Female Workers in the Garment Sector of Bangladesh', Bahar/Spring, 4(1):43-58.

https://www.researchgate.net/publication/282640556_Health_Status_of_the_Female_Workers_in_ the_Garment_Sector_of_Bangladesh

Allain, J., Crane, A., Lebaron, G. \& Behbahani, L. (2013), 'Forced Labour's Business Models and Supply Chains', Joseph Rowntree Foundation.

https://www.jrf.org.uk/sites/default/files/jrf/migrated/files/forced-labour-business-full.pdf

ALR (2016), 'A Study of Labour Conditions in Garment Factories in Myanmar Which are Wholly Korean Owned or in a Joint Venture with Korean Companies', Action on Labour Rights. https://cleanclothes.org/resources/national-cccs/under-pressure [accessed 16 November 2018].

Asfar, R. (2001), 'Sociological Implications of Female Labor Migration in Bangladesh', in R. Sobhan \& N. Khundker (eds), Globalization and Gender: Changing Patterns of Women's Employment in Bangladesh (Dhaka, Centre for Policy Dialogue and University Press), 91-165.

Bank Muñoz, Carolina (2008), Transnational Tortillas: Race, Gender, and Shopfloor Politics in Mexico and the United States (Ithaca, NY, Cornell University Press).

Barrett, P. M., Baumann-Pauly, D. \& Gu, A. (2018), 'Five Years After Rana Plaza: The Way Forward', April, Stern Centre for Business and Human Rights, New York University. https://static1.squarespace.com/static/547df270e4b0ba184dfc490e/t/5ac9514eaa4a998f3f30ae13/ 1523143088805/NYU+Bangladesh+Rana+Plaza+Report.pdf

Bick, R., Halsey, E. \& Ekenga, C. (2018), 'The Global Environmental Injustice of Fast Fashion', Environmental Health, 17(1): 92. https://doi.org/10.1186/s12940-018-0433-7

Britton, Dana (2000), 'The Epistemology of the Gendered Organization', Gender and Society, 14: 418-34. https://doi.org/10.1177/089124300014003004

Busch, L. (2007), 'Performing the Economy, Performing Science: From Neoclassical to Supply Chain Models in the Agrifood Sector', Economy and Society, 36: 437-66. https://doi.org/10.1080/03085140701428399

Butler, S. (2016), 'Bangladesh Fashion Factory Safety Work Severely Behind Schedule', The Guardian, 28 January.

https://www.theguardian.com/world/2016/jan/28/bangladesh-factory-safety-scheme-stalls

California Transparency in Supply Chains Act (2010) SB657. http://www.state.gov/documents/organization/164934.pdf

Caraway, Teri (2007), Assembling Women: The Feminization of Global Manufacturing (Ithaca, NY, Cornell University Press).

Carlson, L. A. \& Bitsch, V. (2018), 'Social Sustainability in the Ready-made-garment Sector in Bangladesh: An Institutional Approach to Supply Chains', International Food and Agribusiness Management Review, 21(2): 269-92. https://doi.org/10.22434/IFAMR2017.0114

CCC (2018), '\#GoTransparent Campaign Win: Primark Publishes Factory Locations', press release, Clean Clothes Campaign.

https://cleanclothes.org/news/2018/02/09/primark-publishes-factory-locations-after-pressure-ofgotransparent-campaign

Cha, Youngjoo (2013), 'Overwork and the Persistence of Gender Segregation in Occupations', Gender and Society, 27: 158-84. https://doi.org/10.1177/0891243212470510

Collinson, David L. \& Hearn, Jeff (eds) (1996), Men as Managers, Managers as Men (London, SAGE). 
CORE Coalition (2017), 'RISK AVERSE? Company Reporting on Raw Material and Sector-specific Risks under the Transparency in Supply Chains Clause in the UK Modern Slavery Act 2015'. https://corporate-responsibility.org/wp-content/uploads/2017/10/171003_Risk-Averse-FINAL-1. pdf [accessed 1 May 2018].

Crane, A., LeBaron, G., Allain, J. \& Behbahani, L. (2019), 'Governance Gaps in Eradicating Forced Labor: From Global to Domestic Supply Chains', Regulation and Governance, 13(1): 86-106. https://doi.org/10.1111/rego.12162

Crenshaw, K. (1991), 'Women of Color at the Center: Selections from the Third National Conference on Women of Color and the Law: Mapping the Margins: Intersectionality, Identity Politics, and Violence Against Women of Color', Stanford Law Review, 43: 1241-3. https://doi.org/10.2307/1229039

Dennis, A. \& Campbell, S. (2017), 'Labour Regime Transformation in Myanmar: Constitutive Processes of Contestation', Development and Change, 48(4): 801-24. https://doi.org/10.1111/dech.12315

Egels-Zanden, N. \& Hansson, N. (2016), 'Supply Chain Transparency as a Consumer or Corporate Tool: The Case of Nudie Jeans Co.', Journal of Consumer Policy, 39(4): 377-95. https://doi.org/10.1007/s10603-015-9283-7

Emmott, Robin \& Blenkinsop, Philip (2018), 'Exclusive: EU Considers Trade Sanctions on Myanmar over Rohingya Crisis', Reuters, 3 October. https://www.reuters.com/article/us-myanmar-rohingya-eu-exclusive/exclusive-eu-considers-tradesanctions-on-myanmar-over-rohingya-crisis-idUSKCN1MD28E

ERGON Associates (2018), 'Modern Slavery Reporting: Is There Evidence of Progress?'. https://ergonassociates.net/publication/modern-slavery-reporting-evidence-progress/ [accessed 15 October 2018].

ETI (2017), 'Briefing for Backbench Business Debate on the Implementation of the Modern Slavery Act 2015', 24 October, Ethical Training Initiative.

https://www.ethicaltrade.org/sites/default/files/shared_resources/eti_briefing_for_backbench_ debate_26_oct_17.pdf

Fair Wear Foundation (2016), 'Myanmar Country Study'. https://www.fairwear.org/resource/myanmar-country-study-2016/

Falk, A., Fehr, E. \& Zehnder, C. (2006), 'Fairness Perceptions and Reservation Wages: The Behavioral Effects of Minimum Wage Laws', The Quarterly Journal of Economics, 121(4): 1347-81. https://doi.org/10.1162/qjec.121.4.1347

Fashion Revolution (2018), 'Fashion Transparency Index'. https://www.fashionrevolution.org/about/transparency/ [accessed 5 December, 2018].

Gardner, T. A., Benzie, M., Börner, J., Dawkins, E., Fink, S., Garrett, R., Godar, J., Grimard, A., Lake, S., Larsen, R. L., Mardas, N., McDermott, C. L., Meyfroidt, P., Osbeck, M., Persson, M., Sembres, T., Sauvat, C., Strassburg, B., Trevisan, A., West, C. \& Wolvekamp, P. (2018), 'Transparency and Sustainability in Global Commodity Supply Chains', World Development. https://doi.org/10.1016/j.worlddev.2018.05.025

Glick, P. \& Fiske, S. T. (2001), 'An Ambivalent Alliance: Hostile and Benevolent Sexism as Complementary Justifications for Gender Inequality', American Psychologist, 56(2): 109. https://doi.org/10.1037//0003-066X.56.2.109

Haque, M. Z. \& Azmat, F. (2015), 'Corporate Social Responsibility, Economic Globalization, and Developing Countries: A Case Study of the Ready-made Garments Industry in Bangladesh', Sustainability Accounting, Management and Policy Journal, 6(2): 166-89. https://doi.org/10.1108/SAMPJ-04-2014-0028

Hill Collins, P. (1990), Black Feminist Thought: Knowledge, Consciousness, and the Politics of Empowerment (Boston, MA, Unwin Hyman). 
Home Office (2015), 'Modern Slavery and Supply Chains Government Response Summary of Consultation Responses and Next Steps'.

https://assets.publishing.service.gov.uk/government/uploads/system/uploads/attachment_data/ file/448200/Consultation_Government_Response_final_2_pdf.pdf

Home Office (2017), 'Transparency in Supply Chains etc. A Practical Guide', Home Office.

https://assets.publishing.service.gov.uk/government/uploads/system/uploads/attachment_data/ file/649906/Transparency_in_Supply_Chains_A_Practical_Guide_2017.pdf

House of Lords and House of Commons Joint Committee on Human Rights (2017), Human Rights and Business 2017: Promoting Responsibility and Ensuring Accountability, Sixth Report of Session 2016-17. https://publications.parliament.uk/pa/jt201617/jtselect/jtrights/443/443.pdf

ILO (2018), 'Better Work Bangladesh Programme (BWB)', International Labour Organization. http://www.ilo.org/dhaka/Whatwedo/Projects/WCMS_402978/lang--en/index.htm

IndustriALL (2019), 'Garment Worker Killed and 50 Injured in Bangladesh Clashes’, 10 January. http://www.industriall-union.org/garment-worker-killed-and-50-injured-in-bangladesh-clashes

Kabir, H., Maple, M. \& Fatema, S. R. (2018), 'Vulnerabilities of Women Workers in the Readymade Garment Sector of Bangladesh: A Caste Study of Rana Plaza', Journal of International Women's Studies, 19(6): Article 14, 224-35.

Kaplan, C. D., Korf, D. \& Sterk, C. (1987), 'Temporal and Social Contexts of Heroin-using Populations: An Illustration of the Snowball Sampling Technique', Journal of Nervous and Mental Disease, 175(9): 566-74. https://doi.org/10.1097/00005053-198709000-00009

Kucera, D. \& Tejani, S. (2014), 'Feminization, Defeminization, and Structural Change in Manufacturing', World Development, 64: 569-82. https://doi.org/10.1016/j.worlddev.2014.06.033

Loconto, A. (2015), 'Assembling Governance: The Role of Standards in the Tanzanian Tea Industry', Journal of Cleaner Production, 107: 64-73. https://doi.org/10.1016/j.jclepro.2014.05.090

Mantouvalou, V. (2018), 'The UK's Modern Slavery Act 2015 Three Years on', Modern Law Review, 81(6): 1017-45. https://doi.org/10.1111/1468-2230.12377

Mariani, R. D. \& Valenti, F. (2013), 'Working Conditions in the Bangladeshi Garment Sector: Social Dialogue and Compliance', TU Delft University of Technology and Fair Wear Foundation. https://www3.fairwear.org/ul/cms/fck-uploaded/documents/countrystudies/bangladesh/ WorkingconditionsintheBangladeshigarmentsectorSocialdialogueandcompliance.pdf [accessed 12 August, 2018].

Martin, Patricia Yancey (2003), "Said and Done" Versus "Saying and Doing": Gendering Practices, Practicing Gender at Work', Gender and Society, 17: 342-66. https://doi.org/10.1177/0891243203017003002

McDermott, C. L. (2014), 'REDduced: From Sustainability to Legality to Units of Carbon-The Search for Common Interests in the International Forest Governance', Environmental Science and Policy, 35: 12-19. https://doi.org/10.1016/j.envsci.2012.08.012

McLaughlin, H., Uggen, C. \& Blackstone, A. (2012), 'Sexual Harassment, Workplace Authority, and the Paradox of Power', American Sociological Review, 77(4): 625-47. https://doi.org/10.1177/0003122412451728

Miller, P. \& Rose, N. (1990), 'Governing Economic Life', Economy and Society, 19: 1-31. https://doi.org/10.1080/03085149000000001

Min, A. \& Kudo, T. (2013), 'New Government's Initiatives for Industrial Development in Myanmar', in H. Lim \& Y. Yamada (eds), Economic Reforms in Myanmar: Pathways and Prospects, BRSC Research Report No. 10, Bangkok Research Center, IDE-JETRO, Bangkok. https://www.ide.go.jp/library/English/Publish/Download/Brc/pdf/10_02.pdf

Modern Slavery Act 2015. (c.30) (London, The Stationery Office). http://www.legislation.gov.uk/ukpga/2015/30/contents/enacted 
Mol, A. P. J. (2009), Environmental Reform in the Information Age: The Contours of Informational Governance (Cambridge, Cambridge University Press). https://doi.org/10.1017/CBO9780511491030

Mol, A. P. J. (2015), 'Transparency and Value Chain Sustainability', Journal of Cleaner Production, 107: 154-61. https://doi.org/10.1016/j.jclepro.2013.11.012

Nielsen, M. E. (2005), 'The Politics of Corporate Responsibility and Child Labour in the Bangladeshi Garment Industry', International Affairs, 81(3): 559-80. https://doi.org/10.1111/j.1468-2346.2005.00469.x

Nolan, J. \& Bott, G. (2018), 'Global Supply Chains and Human Rights: Spotlight on Forced Labour and Modern Slavery Practices', Australian Journal of Human Rights, 24(1): 44-69. https://doi.org/10.1080/1323238X.2018.1441610

Phillips, Andrew, Trautrims, Alexander \& Kenway, Emily (2018), 'Agriculture and Modern Slavery Act Reporting: Poor Performance Despite High Risks: A Research Report from the Office of the Independent Anti-Slavery Commissioner and the University of Nottingham's Rights Lab'. https://www.antislaverycommissioner.co.uk/media/1220/modern-slavery-act-and-agriculturepoor-performance-briefing.pdf [accessed 17 August 2018].

Phillips, N. (2017), 'Power and Inequality in the Global Political Economy', International Affairs, 93(2):429-44. https://doi.org/10.1093/ia/iix019

Plankey Videla, Nancy. (2012), We Are in this Dance Together: Gender, Power, and Globalization at a Mexican Garment Factory (New Brunswick, NJ, Rutgers University Press).

Pozas Garza, María de los Ángeles (2002), Estrategia internacional de la gran empresa Mexicana en la década de los noventa (Mexico City, El Colegio de México).

Preuss, Simone (2018), 'Update: What is Happening with the Bangladesh Accord?', Fashion United, 2 December.

https://fashionunited.uk/news/business/update-what-is-happening-with-the-bangladesh-accord/ 2018120340280

Radio Free Asia (2015), 'Myanmar Garment Workers Threaten Further Strikes if Demands are Not Met', 24 February. https://www.rfa.org/english/news/myanmar/strikes-02242015130920.html

Reinecke, J. \& Donaghey, J. (2015), 'After Rana Plaza: Building Coalitional Power for Labour Rights Between Unions and (Consumption-based) Social Movement Organisations', Organization, 22(5): 720-40. https://doi.org/10.1177/1350508415585028

Ruggie, J. (2013), Just Business: Multinational Corporations and Human Rights (New York, W. W. Norton). Safi, Michael (2018), 'Bangladesh to Eject Safety Inspectors Brought in after Rana Plaza Disaster', The Guardian, 28 November.

https://www.theguardian.com/world/2018/nov/28/international-inspectors-to-leave-bangladeshafter-factory-fire

Salzinger, Leslie (2003), Genders in Production: Making Workers in Mexico's Global Factories (Berkeley, CA, University of California Press).

Selth, A. (2017), 'Suu Kyi’s Myanmar, One Year on', The Interpreter, 27 April. https://www.lowyinstitute.org/the-interpreter/suu-kyi-s-myanmar-one-year

Skrivankova, K. (2010), 'Between Decent Work and Forced Labour: Examining the Continuum of Exploitation', Joseph Rowntree Foundation.

https://www.jrf.org.uk/report/between-decent-work-and-forced-labour-examining-continuumexploitation

SOMO (2017), 'The Myanmar Dilemma: Can the Garment Industry Deliver Decent Jobs for Workers in Myanmar?', Stichting Onderzoek Multinationale Ondernemingen, Amsterdam. https://www.somo.n1/wp-content/uploads/2017/02/The-Myanmar-Dilemma-Summary.pdf [accessed 15 November 2018]. 
Stevenson, M. \& Cole, R. (2018), 'Modern Slavery in Supply Chains: A Secondary Data Analysis of Detection, Remediation and Disclosure', Supply Chain Management: An International Journal, 12(3): 81-99. https://doi.org/10.1108/SCM-11-2017-0382

United Nations (2011), Guiding Principles on Business and Human Rights. https://www.ohchr.org/Documents/Publications/GuidingPrinciplesBusinessHR_EN.pdf

UN News (2017), 'UN Human Rights Chief Points to "Textbook Example of Ethnic Cleansing” in Myanmar', 11 September.

https://news.un.org/en/story/2017/09/564622-un-human-rights-chief-points-textbook-example-ethniccleansing-myanmar

Williams, Christine L. (1995), Still a Man's World: Men Who Do Women's Work (Berkeley, CA, University of California Press).

Williams, Christine L., Muller, Chandra \& Kilanski, Kristine (2012), 'Gendered Organizations in the New Economy', Gender and Society, 26: 549-73. https://doi.org/10.1177/0891243212445466

Williams, Joan C. (2000), Unbending Gender (Oxford, Oxford University Press).

Workforce Disclosure Initiative (2017), 'Myanmar Case Study for the Workforce Disclosure Initiative'. https://shareaction.org/wp-content/uploads/2017/11/CaseStudy-WDI-Myanmar.pdf [accessed 15 November 2018].

Yang, Y. \& Mlachila, M. (2004), 'The End of Textiles Quotas: A Case Study of the Impact on Bangladesh', IMF WP/04/108, International Monetary Fund.

https://www.imf.org/external/pubs/ft/wp/2004/wp04108.pdf;

https://doi.org/10.5089/9781451853131.001

Notes on the authors:

Leona Vaughn is a Post Doctoral Research Associate in the BA-DFID-funded project 'Clothes, Chocolate and Children: Realising the Transparency Dividend' at the University of Liverpool. Her research interests include risk, rights, children, social justice, and participatory methods.

Leona.Vaughn@liverpool.ac.uk

Alex Balch is Professor of Politics at the University of Liverpool. His research focuses on the politics and policy of immigration, and on efforts to combat forced labour and human trafficking. He has worked with a range of funders including AHRC, ESRC, the British Academy, and the Joseph Rowntree Foundation.

A.R.Balch@liverpool.ac.uk

Jennifer Johns is a Reader in International Business, in the Department of Management at the University of Bristol. She is an economic geographer specialising in the spatial and power dynamics of value chains.

jennifer.johns@bristol.ac.uk

Samantha Currie is a Senior Lecturer in the School of Law and Social Justice at the University of Liverpool. Her research interests include: law and policy responses to 
human trafficking; intra-EU migration and mobility; gender and migration; and the cross-border posting of workers.

Samantha.Currie@liverpool.ac.uk

To cite the article: Leona Vaughn, Alex Balch, Jennifer Johns and Samantha Currie (2019), 'Transparency in supply chains and the lived experiences of workers and their families in the garment sectors of Bangladesh and Myanmar', Journal of the British Academy, 7(s1): 35-60.

DOI https://doi.org/10.5871/jba/007s1.035

This article is licensed under a

Creative Commons Attribution-NonCommercial-NoDerivs 4.0 Unported License.

Journal of the British Academy (ISSN 2052-7217) is published by

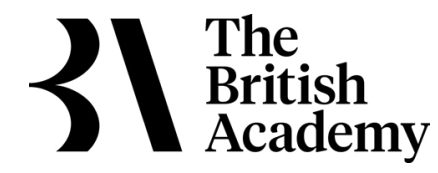

10-11 Carlton House Terrace, London, SW1Y 5AH

www.thebritishacademy.ac.uk 